\title{
EFEKTIVITAS BEBERAPA INSEKTISIDA NABATI TERHADAP HAMA Plutella xylostella Linn. (Lepidoptera; Plutellidae) PADA TANAMAN KUBIS (Brassica oleracea $\mathrm{L}$. ) DI KABUPATEN MINAHASA
}

\author{
Margaretha S. Ginting \\ Jantje Pelealu \\ Betsy A. N. Pinaria
}

\begin{abstract}
This study aims to: (1) Know the effectiveness of plant insecticides plant extracts Tiger Grass, Nutmeg Seeds and Bitung Fruits against cabbage caterpillar Plutella xylostella L. on cabbage plants? (2) Analyzed the mortality of the cabbage of Plutella xylostella $L$. cabbage on cabbage plants in Minahasa Regency on the administration of plant insecticide plant extracts of Nutmeg, Tiger Grass and Bitung Fruit. This research was conducted from July to November 2017 using a Completely Randomized Design (RAL), consisting of 4 treatments and 3 replicates. Field sampling of cabbage plants was conducted on 12 sub-plots. Every 7 days the number of $P$. xylostella larvae is observed. Observations were performed before spraying, and 1 day after spraying, as well as on week II to week V observations, for the collection of P. xylostella pupa done on 1 day after spraying, the number of pupa collected per sub-plot was 5 pupa so that 15 pupa collected, the total number of pupa 60 pupa. Then the pupa collected was placed in the prepared container and then observed the development. The results showed that: (1) The test result from Seed Nut extract, Tiger Grass extract and Bitung Fruit at concentration of $15 \%$ to mortality of Plutella xylostella larvae showed the significant difference of each treatment with the highest mortality rate of Plutella xylostella larvae 87,07\% on Fruit extract treatment Bitung, Tiger Grass extract 78.09 percent, on Seed Nut extract 74.44 percent and 22.55 percent on control. (2) The test result from Seed Extract of Nutmeg, Bitung and Tiger Grass on the mortality of Plutella xylostella larvae showed significant difference of each treatment with higher concentration of extract treatment, the higher the mortality of Plutella xylostella larvae.
\end{abstract}

Keywords: effectiveness of nabati insecticides, pests of Plutella xylostella Linn, cabbage crops, Minahasa District

\begin{abstract}
ABSTRAK
Penelitian ini bertujuan untuk: (1) Mengetahui efektifitas pemberian insektisida nabati ekstrak tanaman Rumput Macan, Biji Pala dan Buah Bitung terhadap ulat kubis Plutella xylostella L. pada tanaman kubis? (2) Menganalisis mortalitas hama kubis Plutella xylostella L. pada tanaman kubis di Kabupaten Minahasa pada pemberian insektisida nabati ekstrak tanaman Biji Pala, Rumput Macan dan Buah Bitung. Penelitian ini dilaksanakan pada bulan Juli sampai bulan November 2017. Menggunakan Rancangan Acak Lengkap (RAL), terdiri atas 4 perlakuan dan 3 Ulangan. Pengambilan sampel tanaman kubis dilapangan dilakukan pada 12 sub-plot. Setiap 7 hari dilakukan pengamatan jumlah larva $P$. xylostella. Pengamatan dilakukan sebelum penyemprotan, dan 1 hari setelah penyemprotan, begitu juga pada pengamatan minggu II sampai minggu $\mathrm{V}$, untuk pengumpulan pupa $P$. xylostella dilakukan pada 1 hari setelah penyemprotan, jumlah pupa yang dikumpulkan setiap sub-plot adalah 5 pupa sehingga 15 pupa terkumpul, dengan jumlah seluruh pupa 60 pupa. Kemudian pupa yang dikumpulkan diletakan dalam wadah yang telah disiapkan lalu diamati perkembangannya. Hasil penelitian menunjukkan bahwa: (1) Hasil uji dari ekstrak Biji Pala, ekstrak Rumput Macan dan Buah Bitung pada konsentrasi 15\% terhadap mortalitas larva Plutella xylostella menunjukan perbedaan nyata tiap perlakuan dengan jumlah mortalitas larva Plutella xylostella tertinggi 87,07 persen pada perlakuan ekstrak Buah Bitung, ekstrak Rumput Macan 78,09 persen, pada ekstrak Biji Pala 74,44 persen dan 22,55 persen pada kontrol. (2) Hasil uji dari ekstrak Biji Pala, Buah Bitung dan Rumput Macan terhadap mortalitas larva Plutella xylostella menunjukan perbedaan nyata tiap perlakuan dengan semakin tinggi konsentrasi perlakuan ekstrak, semakin tinggi pula mortalitas larva Plutella xylostella.
\end{abstract}

Kata Kunci: efektivitas insektisida nabati, hama Plutella xylostella Linn, tanaman kubis, Kabupaten Minahasa 


\section{PENDAHULUAN}

\section{Latar Belakang}

Peningkatan produksi sayuran di Indonesia sangat diperlukan untuk memenuhi kebutuhan dalam negeri guna mengimbangi laju pertambahan penduduk yang semakin meningkat pula. Selain itu, penting juga adanya upaya peningkatan produksi sayuran untuk keperluan ekspor dan substitusi $\mathrm{Hal}$ in isesuai dengan tujuan utama pembangunan nasional di sector pertanian yaitu menaikkan produksi pertanian.

Diantara berbagai jenis hasil pertanian, sayuran merupakan bahan pangan penting penduduk Indonesia yang diperlukan setiap hari. Di antara sayuran yang ditanam kubis (Brassica oleracea) merupakan salah satu produk pertanian yang sangat banyak dibutuhkan bagi sebagian besar masyarakat. Produksi kubis selain untuk pemenuhan kebutuhan dalam negeri juga merupakan komoditas ekspor yang termasuk kelompok enam sayuran komoditi ekspor unggulan Indonesia (Rukmana, 1994). Luas tanaman kubis di Indonesia pada tahun 2013 mencapai 65,248 ha dengan produksi 1.480 .625 ton (BPS, 2013).

Hama ulat daun kubis Plutellaxylostella L. (Lepidoptera: Plutellidae ) merupakan salah satu jenis hama utama di pertanaman kubis. Apabila tidak ada tindakan pengendalian, kerusakan kubis oleh hama tersebut dapat meningkat dan hasil panen dapat menurun baik jumlah maupun kualitasnya. Serangan yang timbul kadang-kadang sangat berat sehingga tanaman kubis tidak membentu krop dan panennya menjadi gagal. Kehilangan hasil kubis yang disebabkan oleh serangan hama dapat mencapai 10 - $90 \%$. Ulat daun kubis P. xylostella bersama dengan ulat jantung kubis Croci dolomia pavonana F. mampu menyebabkan kerusakan berat dan dapat menurunkan produksi kubis sebesar 79,81\%. Kondisi seperti ini tentu saja merugikan petani sebagai produsen kubis. Oleh karena itu upaya pengendalian hama daun kubis ini sebagai hama utama tanaman kubis perlu dilakukan untuk mencegah dan menekan kerugian akibat serangan hama tersebut.

Oleh karena itu, perlu dicari cara pengendalian yang efektif terhadap hama sasaran namun aman terhadap organisme bukan sasaran dan lingkungan. Salah satu golongan insektisida yang memenuhi persyaratan tersebut adalah insektisida yang berasal dari tumbuh-tumbuhan (insektisida nabati) (Martono $d k k, \quad 2004)$. Pemanfaatan bahan tumbuhan bisa mengurangi bahaya untuk kesehatan manusia dan ternak dan pengurangan biaya produksi untuk penggunaan pestisida kimia (Sudarmo, 2005). Hal ini sejalan dengan program pemerintah dalam hal perlindungan tanaman dalam penerapan teknik Pengendalian Hama Terpadu sesuai dengan Inpres no. 3 tahun 1998, maka perlu diterapkan alternative dalam pengendalian hama yang dikembangkan seperti pestisida nabati (botani) yang merupakan produk alam yang ramah lingkungan dan tidak meninggalkan residu pada tanaman.

Jenis tumbuhan yang dapat dijadikan insektisida nabati antara lain adalah, Lantana camara L. (rumputmacan), pala dan buah bitung. Bahan-bahan tersebut telah teruji keampuhannya dalam mengendalikan hama tanaman, pestisida dari bahan-bahan tersebut biasanya digunakan untuk racun serangga dan pembasmi cendawan (Prihatman, 2000a).

Insektisida nabati mempunyai bahan aktif yang dapat digunakan untuk mengendalikan hama. Rumput macan merupakan gulma beracun dan berbau sangat menyengat. Bau menyegat disebabkan oleh karena adanya kandungan senyawa phenol dalam tanaman tersebut, sifat meracun Rumput Macan disebabkan adanya bahan aktif Triperpenoid Lantandene A (steenis, 1987), pada tanaman pala yang digunakan dalam penelitian ini adalah biji pala karena mengandung minyak atsiri yang dapat digunakan mengendalikan berbagai serangga yang terdiri dari miristisin dan monoterpenamonoterpena lain. Buah bitung bijinya mengandung komponen utama saponin dan trterpenoid. Berdasarkan hal diatas peneliti akan menggunakan bahan tumbuhan sebagai pestisida nabati agar bisa mengurangi kerugian dan pencemaran lingkungan dari penggunaan bahan pestisida kimi

\section{PerumusanMasalah}

Berdasarkan latar belakang diatas maka dapat dirumuskan permasalahannya sebagai berikut :

1. Apakah ekstrak tanaman Rumput Macan, biji pala dan buah bitung efektif dalam pengendalian hama ulat Plutella xylostella $L$ 
pada tanaman kubis di Kabupaten Minahasa?

2. Apakah konsentrasi $15 \%$ pada setiap ekstrak tanaman Rumput Macan, biji pala dan buah bitung efektif dalam pengendalian hama ulat Plutella xylostella L.. pada tanaman kubis di Kabupaten Minahasa?

\section{Tujuan Penelitian}

1. Mengetahui efektifitas pemberian insektisida nabati ekstrak tanaman Rumput Macan, biji pala dan buah bitung terhadap ulat kubis Plutella xylostella L. pada tanaman kubis?

2. Mengetahui konsentrasi $15 \%$ pada setiap ekstrak tanaman Rumput Macan, biji pala dan buah bitung, ekstrak mana yang paling efektif terhadap ulat krop kubis Plutella xylostella L.. pada tanaman kubis di Kabupaten Minahasa.

\section{Manfaat Penelitian}

Dapat memberikan informasi mengenai efektifitas pemberian insektisida nabati dan ramah lingkungan pada ekstrak tanaman Rumput Macan, biji pala dan buah bitung terhadap ulat Plutella xylostella L. pada tanaman kubis, dan menegetahui konsentrasi ekstrak yang mana paling efektif dalam pengendaliannya di Kabupaten. Minahasa.

\section{Hipotesis}

1. Diduga pengendalian dengan ekstrak Buah Bitung dan Rumput Macan dapat menyebabkan mortalitas yang tinggi terhadap hama $P$. xylostella.

2. Diduga bahwa ekstrak Buah Bitung pada konsentrasi $15 \%$ memiliki efektivitas yang tinggi untuk mengendalikan hama $P$. xylostella.

\section{METODOLOGI PENELITIAN}

\section{Tempat dan Waktu}

Penelitian dilaksanakan di Laboratorium FMIPA Universitas Kristen Indonesia di Tomohon dan dilahan pertanaman kubis di Kelurahan Tataaran Patar, Kecematan Tondano Selatan. Penelitian ini dilaksanakan dari bulan Juli sampai bulan November 2017.

\section{Bahan dan Alat penelitian}

Bahan yang digunakan dalam penelitian ini tanaman kubis berumur 2 minggu, larva $P$. xylostella instar 3, biji pala, daun rumput lantana camara, biji buah bitung, aquades, methanol.

Alat-alat yang dipakai yaitu timbangan, alumunium foil, sendok, erlenmeyer $500 \mathrm{ml}$, gelas ukur, pinset, gunting, kain kasa, kertas label, sungkup plastik, kain lap, kamera, kertas saring, hand sprayer, pisau, blender dan toples plastik.

(K). Kontrol

(A). Ekstrak Biji Pala

(B). Ekstrak Rumput Macan

(C). Ekstrak Buah Bitung

Pengambilan sampel tanaman kubis dilapagan pada 12 sub plot. Setiap 7 hari dilakukan pengamatan jumlah larva $P$. xylostella.

Pengamatan dilakukan sebelum penyemprotan, dan 1 hari setelah penyemprotan, begitu juga pada pengamatan minggu II sampai minggu $\mathrm{V}$,

Subplot yang digunakan pada lokasi pengamatan tertera pada gambar berikut ini:

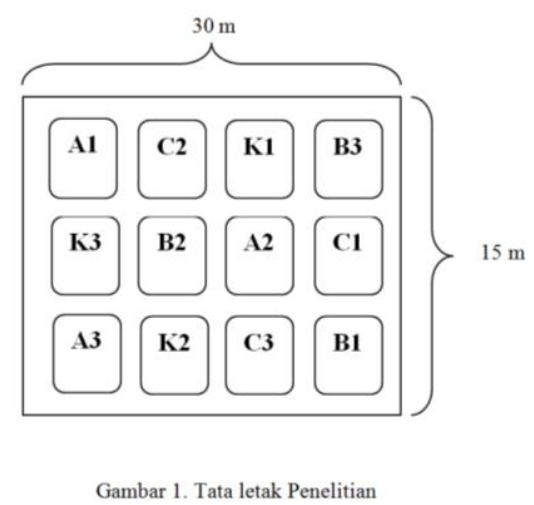

untuk pengumpulan pupa $P$. xylostella dilakukan pada 1 hari setelah penyemprotan, jumlah pupa yang dikumpulkan setiap sub plot adalah 5 pupa sehingga 15 pupa terkumpul, dengan jumlah seluruh pupa 60 pupa. Kemudian pupa yang dikumpulkan diletakan dalam wadah yang telah disiapkan lalu diamati perkembangannya.

\section{Prosedur penelitian}

\section{Persiapan Lahan dan Tanaman kubis}

Lahan dibersihkan terlebih dahulu, kemudian dibuat bedeng sesuai perlakuan, selanjutnya dibuat sub plot dengan ukuran masing-masing jarak tanam $50 \mathrm{~cm}$ x $40 \mathrm{~cm}$. (Gambar 1 dan Gambar 2). 


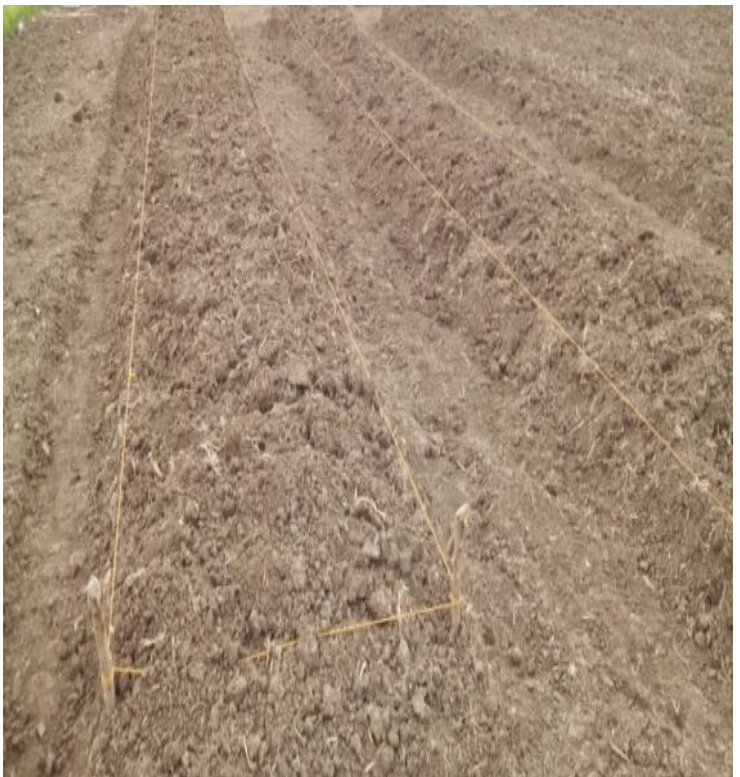

Gambar 2. Lokasi penelitian

\section{Pembibitan Tanaman Kubis}

Kubis yang digunakan adalah benih kubis jenis hibrida F1 yang dibedeng dalam bibit pembedengan dahulu, setelah itu baru dipindahkan kebedengan yang disiapkan setelah berumur 2 minggu atau 14 hari untuk masingmasing percobaan ekstraksi (Gambar 3).

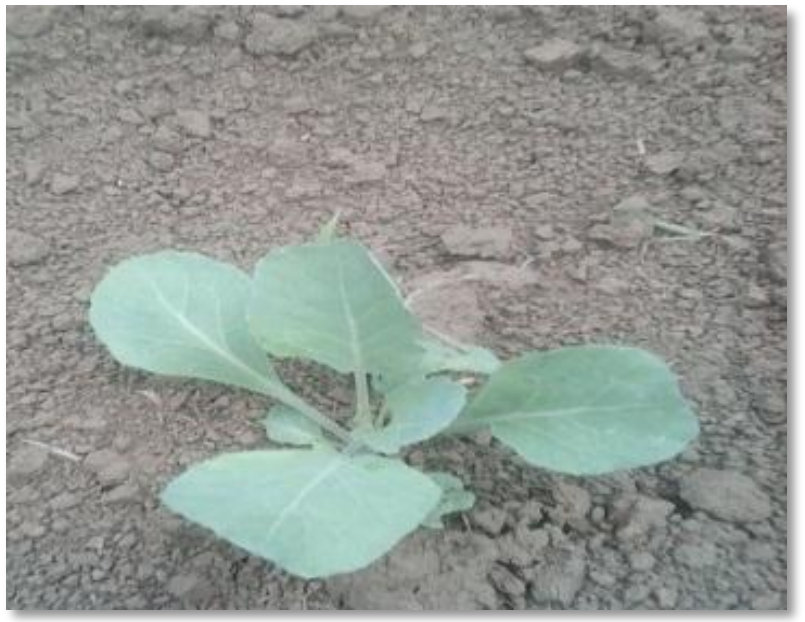

Gambar 3.Pembibitan

\section{Penanaman Kubis}

Bibit ditanam pada lahan yang sudah disiapkan satu persatu. Tanaman disiram teratur sebanyak 2 kali sehari dan juga pengendalian gulma secara mekanis dengan mencabut gulma yang tumbuh disekitar tanaman. Dalam penyiangan dilakukan 2 kali yaitu pada tanaman berumur 20 hst dan 40 hst (Gambar 4).

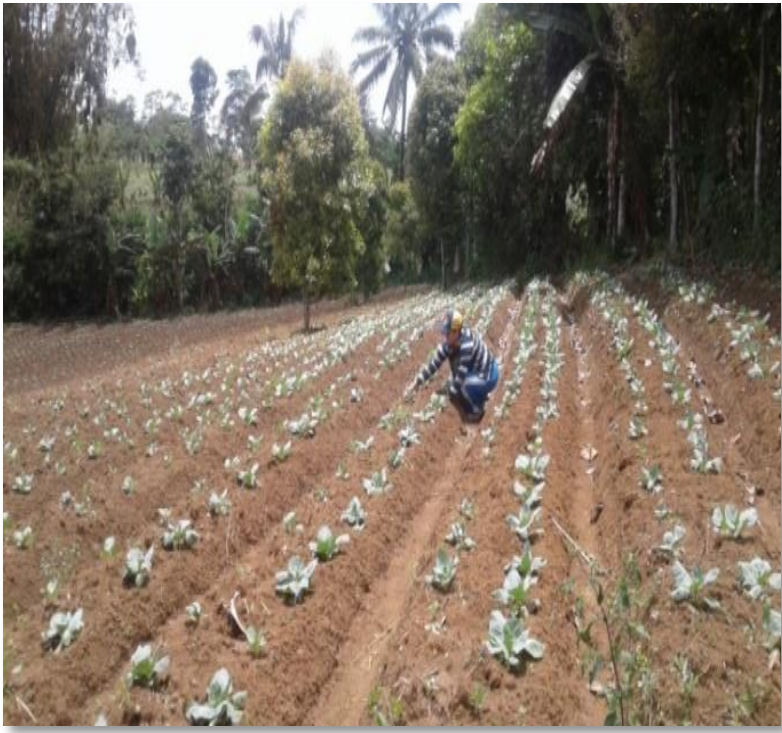

Gambar 4.Penanamankubis

\section{Pembuatan Ekstrak biji pala, daun lantana camara dan buah bitung}

Biji pala dan biji buah bitung dicuci, ditiriskan lalu dikering anginkan diatas kertas Koran selama 14 hari sampai menghasilkan berat kering (gram). Setelah kering masing-masing ditimbang sebanyak $1 \mathrm{~kg}$ kemudian dipotong kecil-kecil ukuran $1 \mathrm{~cm}$ dan diblender sampai menjadi serbuk. Serbuk tersebut di timbang masing-masing sebanyak 200 gram. Untuk perlakuan masing-masing ekstrak direndam dengan pelarut methanol sebanyak $800 \mathrm{ml}$ setiap ekstrak selama 3 × 24 jam. Begitu juga dengan daun lantana camara. Kemudian larutan disaring memakai kertas saring untuk memisahkan residu dari larutan, kemudian diuapkan menggunakan oven dengan suhu $64^{0} \mathrm{C}$ selama 3 jam. Hasil ekstrak tersebut masing-masing dari larutan ekstrak tersebut sampai didapatkan masing-masing $325 \mathrm{ml}$ Buah bitung, $325 \mathrm{ml}$. Rumput Macan dan Biji Pala $325 \mathrm{ml}$, kemudian dimasukkan dalam wadah dan ditutup dengan alumunium foil dan disimpan dalam lemari es sebagai hasil dari ekstrak. Sedangkan ekstrak kasar hasil ekstraksi dilarutkan dengan pelarut aquades dengan konsentrasi $15 \%$ sebagai perlakuan pada tanaman kubis. Larutan dengan konsentrasi $15 \%$ tersebut kemudian dimasukkan dalam masing-masing hand sprayer sebagai perlakuan pada tanama kubis. 


\section{Aplikasi penyemprotan}

Aplikasi dilakukan dengan menyemprotkan setiap ekstrak pada masing-masing perlakuan setelah dipindahkan kebedengan yang telah di beri label. Penyemprotan ekstrak dilakukan pada waktu tanaman berumur $14 \mathrm{hst}$, penyemprotan dilakukan pada sore hari mulai dari pukul 16.00-18.00. Sebelum penyemprotan, sekitar tanaman diberi sungkup supaya tidak tersemprot ketanaman sebelahnya. Dengan menggunakan hand sprayer, ekstrak diaplikasi keseluruh bagian tanaman. Ukuran hand sprayer disesuaikan dengan banyaknya ekstrak. Satu perlakuan ekstrak dibagi ke 5 tanaman ulangan dan tiap tanaman disemprot 5 kali dengan jarak 10 $\mathrm{cm}$ dari tanaman. (Gambar 5). Setelah disemprotkan dengan konsentrasi ekstrak perlakuan, larva percobaan yang disiapkan dipindahkan dengan menggunakan kuas kecil.

Sehari setelah perlakuan, larva dipindahkan kedlam wadah steril berisi kapas basah dengan daun kubis sebagai bahan makannya. Pengamatan dilakukan sejak itu dn dilanjutkan setiap hari selama 10 hari

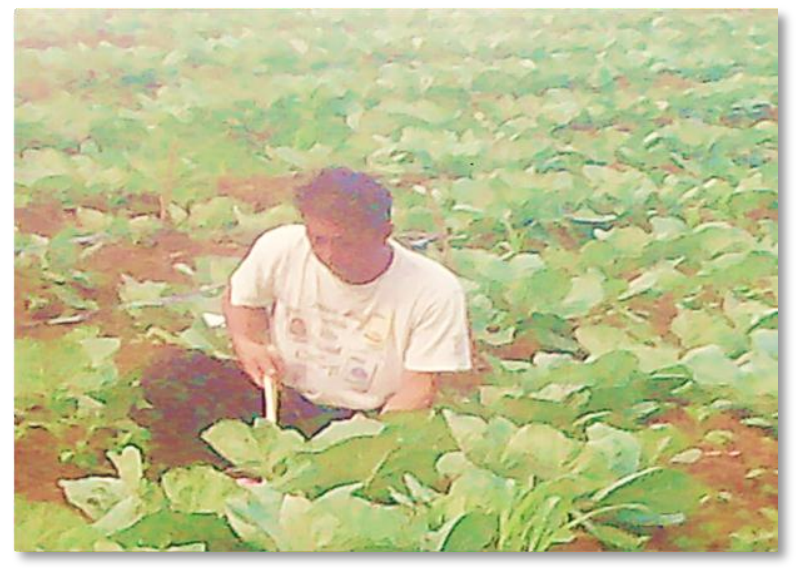

Gambar 5. Aplikasi penyemprotan ekstrak

\section{Variable Pengamatan}

a. Gejala Serangan dan perubahan morfologis tubuh pada larva yang terinfeksi

b. Jumlah larva yang mati.

$$
\begin{aligned}
& \text { Analisa Data } \\
& \text { Hasil pengamatan dianalisis dengan } \\
& \text { menggunakan rumus : } \\
& \qquad \quad \mathbf{P}=\frac{\boldsymbol{x}}{\boldsymbol{y}} \mathbf{x} \mathbf{1 0 0 \%} \\
& \text { Keterangan : } \\
& \mathrm{P}=\text { persentase Mortalitas larva }(\%) \\
& \mathrm{x}=\text { Jumlah larva yang mati }
\end{aligned}
$$

$\mathrm{y}=$ Jumlah larva yang diuji/diamati

Data yang diperoleh dilakukan secara statistik, dan untuk mengetahui tingkat signifikan antar perlakuan, setelah itu dianalisis secara statistik dilakukan dengan menggunakan uji beda nyata terkecil (BNT) 5\%.

\section{HASIL DAN PEMBAHASAN}

\section{Gejala Larva $P$. xylostella yang terinfeksi}

Gejala yang terlihat pada larva $P$. xylostella sehari sesudah perlakuan, menunjukan kurang aktif dan mulai berkurangnya aktifitas makan. Sehingga beberapa tanaman dengan konsentrasi ekstrak tinggi terlihat minimnya jumlah gerekan pada daun tanaman. Gejala ini terlihat dari sedikit gerakan hama pada daun Kubis. Hal ini mengindikasikan berkurangnya kemampuan makan P. xylostella (Gambar 6).

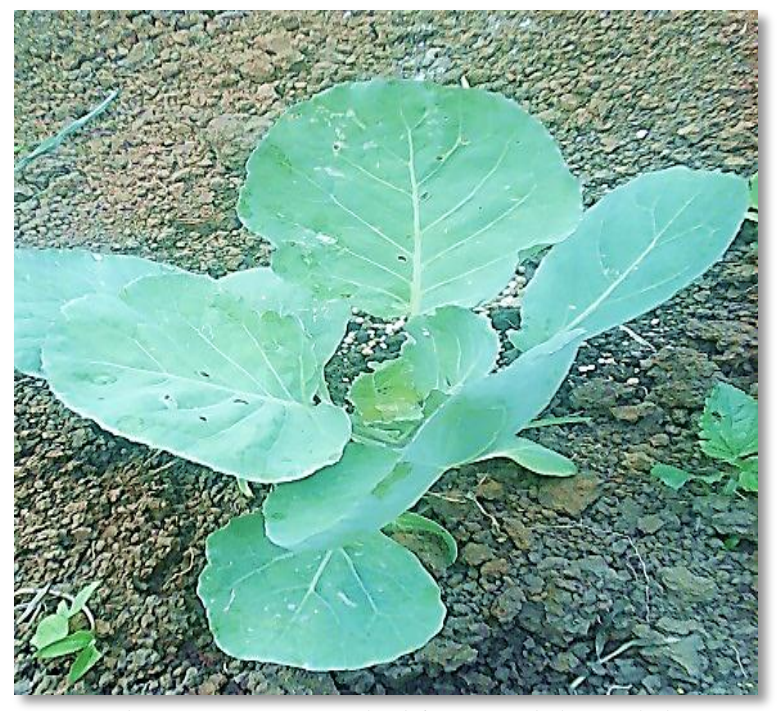

Gambar 6.Tanaman kubis sesudah perlakuan

Hasil pengamatan disebabkan oleh senyawa saponin, flavonoid, antifidan dan minyak atsiri di masing-masing insektisida nabati, yang menghambat makan dan bersifat toksik sehingga dapat menyebabkan kematian larva. Gangguan tubuh pada larva juga disebabkan adanya pembentukan prostaglandin. Prostaglandin berperan dalam proses inflamasi dan peningkatan suhu tubuh. Apabila prostaglandin tidak dihambat akan terjadi peningkatan suhu tubuh yang mengakibatkan demam (Hidayati, 2008).

Terdapat beberapa perlakuan yang tidak mematikan larva, sehingga bisa bertahan hidup dan menjadi pupa. Seperti senyawa antifidan hanya menghambat nafsu makan pada serangga 
dan menekan aktifitas menggigit (suppressant). Sedangkan saponin yang terdapat pada ekstrak Rumput Macan dan ekstrak B. asiatica menurunnya aktivitas enzim pencernaan. Sihaya dkk., (2014) mengemukakan saponin dapat mengikat sterol yang dibutuhkan dalam proses penggantian kulit pada serangga. Poinar dan Thomas menyatakan bahwa gejala awal infeksi patogen pada serangga yang terinfeksi adalah serangga kelihatan lemah, tidak aktif serta makan berkurang.

Pada larva yang terinfeksi warna tubuh menjadi hijau muda dan atau kekuningan dari warna tubuh larva normal yang terdapat pada kontrol yang berwarna hijau (Gambar 7). Jika disentuh tubuh larva menjadi lunak dan sangat lembek, larva kemudian berubah warna menjadi kecoklatan. Larva menjadi kaku, mati dan kering.

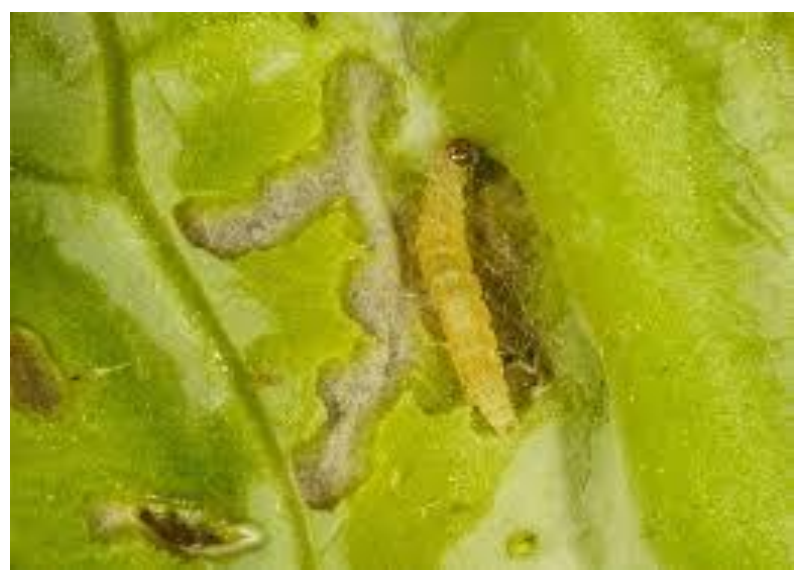

Gambar 7. Larva P. xylostella yang terinfeksi

Pada umumnya saluran pencernaan serangga adalah organ tubuh yang pertama kali infeksi. Hal ini berhubungan degan aktifita makan larva dan pengelolahan bahan makanan. Larva yang memakan tanaman dengan perlakuan terinfeksi disaluran pencernaan. Wiratno (2010) mengemukakan bahwa kerusakan atau cacatnya stadia lanjut $P$. xylostella diduga terjadi akibat senyawa-senyawa toksik yang merusak jaringan saraf, seperti senyawa alkaloid yang dapat menghambat proses larva menjadi pupa, serta dapat memutuskan atau dapat menggagalkan metamorphosis hama yang memiliki metamorphosis sempurna.

\section{Mortalitas larva $P$. xylostella setelah aplikasi perlakuan}

Hasil pengamatan dari minggu I sampai minggu $\mathrm{V}$ menunjukan bahwa persentase mortalitas larva $P$. xylostella pada kontrol bervariasi antara 8,42 - 22,55 persen cenderung lebih rendah dibandingan dengan persentase mortalitas pada perlakuan dengan Biji Pala denga persentase mortalitas yang bervariasi antara 25,91 - 72,81 sedangkan pada mortalitas pada Rumput Macan juga persentasenya terbilang tinggi yaitu 45,85 - 77,94 persen. Namun mortalitas yang lebih tinggi adalah ekstrak Buah Bitung, dengan mortalitas 51,69 - 87,3 persen (Gambar 16 dan Lampiran 1 -5). Berdasarkan hasil analisis sidik ragam ternyata dalam perlakuan terdapat perbedaan yang nyata pada minggu II, dan sangat nyata pada minggu I, III, IV dan V

\begin{tabular}{cccccc} 
Tabel 1. Mortalitas Larva P. xylostella pada periode pengamatan dari minggu I - V \\
\hline Perlakuan & \multicolumn{5}{c}{ Minggu } \\
\cline { 2 - 6 } & I & II & III & IV & V \\
\cline { 2 - 6 } & \multicolumn{5}{c}{$(\%)$} \\
\hline Kontrol & 8,98 & 10,15 & 8,42 & 21,98 & 22,55 \\
Biji Pala & 26.00 & 39,40 & 47,69 & 56,82 & 74,44 \\
Rumput Macan & 51,31 & 46,84 & 52,54 & 71,36 & 78,09 \\
Buah Bitung & 52,70 & 57,57 & 65,14 & 74,28 & 87,30 \\
\hline
\end{tabular}

Dari Gambar 8 dan Tabel 1 terlihat bahwa pengaruh konsentrasi ekstrak angka ratarata mortalitas larva $P$. xylostella mengalami peningkatan tiap periode pengamatan. Hal ini diduga bahwa senyawa-senyawa fitokimia yang terdapat pada ekstrak Biji Pala, Rumput Macan dan Buah Bitung yang menjadi racun perut pada serangga dapat menyebabkan kematian pada larva. Persentase mortalitas minggu I dan minggu III cenderung rendah pada Perlakuan Kontrol, dikarenakan waktu penyemprotan di bulan agustus terjadi curah hujan yang tinggi sehingga menurut Kasep (2012), curah hujan yang terlalu tinggi juga dapat menurunkan akifitas serangga. Karena curah hujan umumnya memberikan pengaruh fisik secara langsung pada kehidupan koloni serangga, karena itu hujan yang intensitas tinggi dan berangsung lama dapat menyebabkan larva menjadi bekurang saat dilakukan pengamatan. 




Gambar 8. Diagram Batang Mortalitas larva P. xylostella dengan perlakuan konsentrasi $15 \%$ setiap ekstrak perlakuan pada periode pengamatan dari minggu I sampai Minggu V.
Hasil pengamatan minggu III sampai V menunjukan infeksi oleh Buah bitung menunjukan pengaruhnya mulai tinggi, hal ini disebabkan kandungan kimia dalam ekstrak Buah bitung, yang mampu membunuh larva. Pada minggu $\mathrm{V}$ tanaman mulai memasuki fase pembentukan krop, dimana fase ini populasi hama $P$. xylostella semakin berkurang. Larva $C$. binotalis yang dikenal sebagai ulat krop kubis lebih mendominasi, oleh sebab itu saat populasi $P$. xylostella berkurang semakin tinggi mortalitas.

Hasil analisis statistik pada minggu I, II, IV dan V mortalitas larva $P$. xylostella pada kontrol berbeda dengan ekstrak Biji Pala, $L$. camar dan Buah Bitung. Sedangkan antara perlakuan Rumput Macan dan Buah Bitung terlihat sedikit tidak berbeda nyata. Sementara pada minggu III kontrol berbeda nyata dengan perlakuan Biji Pala, Rumput Macan dan Buah Bitung, selanjutnya antara perlakuan Biji Pala dan Buah Bitung juga terdapat perbedaan yang nyata (Tebel 1). Hasil ini membuktikan bahwa mortalitas larva $P$. xylostella terendah pada kontrol, kemudian diikuti oleh Biji Pala, Rumput Macan dan Buah Bitung. Jumlah larva P. xylostella mati Biji pala tertinggi ditemukan pada minggu IV dan minggu $\mathrm{V}$ sebesar 11,6 persen, sedangkan jumlah larva $P$. xylostella yang mati pada perlakuan ekstrak Rumput Macan ditemukan juga pada minggu II sebesar 13,6 persen, pada Buah Bitung jumlah larva $P$. xylostella tertinggi sebesar 16,3 persen pada minggu I, sementara kontrol 5,0 persen pada minggu IV
Tabel 2. Mortalitas larva $P$. xylostella pengamatan minggu pertama sampai kelima

\begin{tabular}{cccccc}
\multicolumn{5}{c}{ pertama sampai kelima } \\
\hline Perlakuan & \multicolumn{5}{c}{ Pengamatan } \\
& I & II & III & IV & V \\
\hline Kontrol & $2,0 \mathrm{a}$ & $3,0 \mathrm{a}$ & $2,0 \mathrm{a}$ & $5,0 \mathrm{a}$ & $2,6 \mathrm{a}$ \\
Biji Pala & $16 \mathrm{~b}$ & $20,6 \mathrm{~b}$ & $24,3 \mathrm{~b}$ & $28 \mathrm{~b}$ & $32 \mathrm{ab}$ \\
$\begin{array}{c}\text { Rumput } \\
\text { Macan }\end{array}$ & $18 \mathrm{~b}$ & $18,6 \mathrm{~b}$ & $20,3 \mathrm{~b}$ & $29,6 \mathrm{~b}$ & $23,3 \mathrm{~b}$ \\
Buah & $18,3 \mathrm{~b}$ & $19,3 \mathrm{~b}$ & $23,0 \mathrm{~b}$ & $27,6 \mathrm{~d}$ & $31,6 \mathrm{~b}$ \\
Bitung & & & & &
\end{tabular}

Keterangan : Angka yang diikuti oleh huruf yang sama pada kolom yang sama menunjukan tidak berbeda nyata pada taraf $5 \%$.

Adanya mortalitas larva pada kontrol dimungkinkan karena adanya penyebaran spora secara alami yang terjadi di lapang karena jarak anara sub plot perlakuan cukup berdekatan sehingga terjadinya perpindahan.

Meski perlakuan ekstrak Biji Pala menunjukan angka mortalitas lebih rendah dibandingan dengan angka mortalitas perlakuan ekstrak Buah Bitung (Lampiran 6), tetapi perlakuan ekstrak Biji Pala menunjukan potensi yang sama dalam uji daya bunuh terhadap larva $P$. xylostella seperti pada masing-masing perlakuan ekstrak Rumput Macan dan Buah Bitung. Hal ini juga menjadi bahan pertimbangan dalam penelitian lebih lanjut untuk tiap perlakuan ekstrak pada penelitian ini.

\section{KESIMPULAN DAN SARAN}

\section{Kesimpulan}

Dari hasil penelitian ini dapat disimpulkan bahwa

1. Hasil uji dari ekstrak Biji Pala, Buah Bitung dan Rumput Macan terhadap mortalitas larva $P$. xylostella menunjukan perbedaan nyata tiap perlakuan dengan semakin tinggi konsentrasi perlakuan ekstrak, semakin tinggi pula mortalitas larva P.xylostella.

2. Hasil uji dari ekstrak Biji Pala, ekstrak Rumput Macan dan Buah Bitung pada konsentrasi $15 \%$ terhadap mortalitas larva $P$. xylostella menunjukan perbedaan nyata tiap perlakuan dengan jumlah mortalitas larva $P$. xylostella tertinggi 87,3 persen pada perlakuan ekstrak Buah Bitung, ekstrak Rumput Macan 77,94 persen, pada ekstrak Biji Pala 72,81 persen dan 22,55 persen pada kontrol. 


\section{Saran}

Ekstrak Buah bitung dan ekstrak Biji pala memiliki potensi uang bisa dikembangkan sebagai pestisida botani terhadap hama Plutella xylostella pada tanaman Kubis, dan juga bisa dikembangkan terhadap hama-hama lain pada tanaman ini.

Perlu juga dilakukan penelitian lebih lanjut mengenai pengaruh ekstrak Biji Pala, ekstrak Rumput Macan dan ekstrak Buah Bitung. Hal ini disesuaikan dengan konsep pengendalian hayati yang mengutamakan pengendalian hama sebelum memasuki tahap yang merusak secara ekonomi.

\section{DAFTAR PUSTAKA}

Anonim, 2015b. Tanaman Kubis. Https://Id.Wikipedia.Org/Wiki/Kubis. Diakses Tanggal 2 Juli 2015.

Asep Hermawan., (2005). Penelitian Bisnis Paradigma Kuantitatif, Jakarta : Gramedia. Widiasarana Indonesia.

Badan Pusat Statistika Sulawesi Utara, 2014. Produksi Sayuran Di Kota Tomohon.

Capinera, J. L. 2005. Diamondback Moth Plutella xylostella (Linnaeus) Distribution-DescriptionLife Cyle-Host Plants-Demage-Natural EnemiesWeather-Management-Host Plants ResistenceSelected References. Departemen Of Entomology And Nematology, University Of Florida. Electronic Data Information Source. Publication Number: EENY-105.

Dalimartha, S. 2009. Atlas Tumbuhan Obat Indonesia Jilid 6. Pustaka Bunda, Grup Puspa Swara, Anggota IKAPI. Jakarta.

Dono, D., S. Ismayane, Idar, D. Prijono, dan I Muslikha (2010). Status Dan Mekanisme Risestensi Biokimia Crocidolomic pavonana (F) (Lepodoptera : Crucilidae) Terhadap Insektisida Botani Ekstrak Biji Baringtonia Asiatica. J. Entomol. Ind 7 (I) : 9 - 27

Hartono, T., 2012. Saponin. Http://Www.Farmasi.Dikti. Net, Diakses Pada Tanggal 25 Februari 2013.

Hermintato, S. 2010. Hama Ulat Daun Kubis Plutella Xylostella L. dan Upaya Pengendliannya. Http://Www.Gerbangpertanian.Com/2010/08/Ham a-Ulat-Daun-Kubis-Plutella.Html. Diakses Tanggal 23 Juni 2015.

Hidayat, N. N., Yuliani, dan Kuswanti N. 2013. Pengaruh Ekstrak Daun Suren Dan Daun Mahoni Terhadap Mortalitas dan Aktivitas Makan Ulat Daun Plutella xylostella Pada Tanaman Kubis. Fakultas MIPA. Universitas Ngeri Surabaya.

Hidayati, N. A., S. Listyawati dan A. D. Setyawan. 2008. Kandungan Kimia Dan Uji Antiinflamasi Ekstrak Etanol Lantana camara L. Pada Tikus Putih (Rattus norvegicus L.) Jantan. Bioteknologi. 5: 1017.
Kasep, 2013. Faktor Fisik Yang Mempengaruhi Hama Tanaman. Http://Forester.Untad.Com/2013/07/ Faktor-Fisik-Yang-Mempengaruhi-Hama.Html. Diakses Tanggal 28 April 2015

Kalshoven, L. G. E. 1981. The Pests Of Crops In Indonesia. Revised By P. A. Van Deer Lan. PT. Ichtiar Baru, Van Hoeve. Jakarta.

Martono, B. E. Hadipoertyanti, Dan L. Udarmo. (2004). Plasma Nutfah Insektisida Nabati. Balai Peneitian Tanaman Rempah \& Obat.

Pelealu J. 2005. Preferensi Plutella xylostella Linn. (Lepidoptera; Yponomeutidae) pada Beberapa Jenis Brassicaceae. Fakultas Pertanian UNSRAT Manado.

Pracaya. 2009. Hama dan Penyakit Tanaman. Penebar Swadaya. Jakarta.

Prihatman, K., 2001. Tentang Budidaya Pertanian : Kedelai. Deputi Menegristek Bidang Pendayagunaan dan Pemasyarakatan Ilmu Pengetahuan dan Teknologi.

R. Rahardian, Hadi, M. U. Tartmotjo : (2009). Biologi Insekta : Entomologi. Yogyakarta : Graha Ilmu.

Rhardian, D. 2009. Pengaruh Ekstrak Biji Pala (Myristica Fragrans Houtt) Dosis 7,5 Mg/25grbb Terhadap Waktu Induksi Tidur Dan Ama Waktu Tidur Mencit BALB/C yang Diinduksi Thipental. Fakultas Kedokteran Universitas Diponegoro, Semarang.

Rukmana, R. 1994. . Budi Daya Kubis Bunga \& Brokoli. Kanisius. Yogyakarta

Rukmana, R. 2010. Bertanam Kubis. Yogyakarta : Kanisius.

Salaki, C. L., Paendong E., dan Pelealu J. 2012. Biopestosida Dari Ekstrak Daun Pangi (Pangium Sp) Terhadap Serangga Plutella xylostella Di Sulawesi Utara. Fakultas Pertanian UNSRAT. Manado.

Septiarusli,. I. E. 2012. Potensi Senyawa Metabolit Sekunder Dari Ekstrak Biji Buah Keben (Baringtonia asiatica) Dalam Proses Anastesi Ikan Kerapu Macan (Ephiriphelis fusciguttatis). Skripsi. Fakultas Perikanan dan Ilmu Kelautan, Universitas Pajajaran,. Jatinagor, Bandung.

Siahaya, V. G., dan R. Y. Rumthe. 2014. Uji Ekstrak Daun Pepaya (Carica papaya L) Terhadap Larva Plutella xylostella (Lepidoptera; Pletellidae). Fakultas Pertanian. Universitas Pattimura. Ambon.

Sudarmo, S. 2005. Pestisida Nabati dan Pemanfaatannya. Yogyakarta : Kanisius

Tan, R. 2001. Sea Poison Tree Barringtonia Asiatica. Available Online At

Www.Natuna.Per.Sg/Buloh/Sea_Poison.Html. Diakses Tanggal 10 Maret 2013.

Tan, R. X And W. X. Zou, (2001). Endoplyte : A Rich Source Of Fungtional Metabolite Nat. Prod, Rep, 18: $448-459$

Van Stienis, G. Bwembergen \& P. J., Eyma., 2003. Flora Untuk Sekolah Di Kolombia Proudnya Paramita, Jakarta

Wiratno. 2010. Beberapa Formula Pestisida Nabati Dari Cengkeh. Jurnal Agritek. 